\title{
$\nabla$ Rural Healthcare Infrastructure of North-East India and its Challenges
}

\section{IJCRR}

Section: Healthcare

ISI Impact Factor

(2019-20): 1.628

IC Value (2019): 90.81

$\operatorname{SJIF}(2020)=7.893$

(c) (7) (8)

Copyright@IJCRR

\section{Manuranjan Gogoi ${ }^{1}$, Sarat Hazarika ${ }^{2}$, Khirod Kr. Phukan³ ${ }^{3}$ Purabi Gogoi ${ }^{4}$}

'Assistant Professor (Contract), Department of Economics, Madhabdev University, Narayanpur, Assam, India; ${ }^{2}$ Registrar i/c, Madhabdev

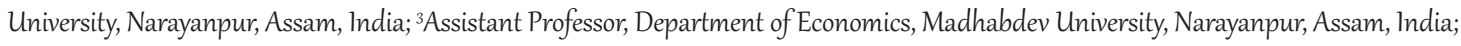
${ }^{4}$ Assistant Professor, Department of Economics, T.H.B. College, ]amugurihat, Sonitpur, Assam, India.

\section{ABSTRACT}

Introduction: There is a vast change in healthcare infrastructure in the twenty-first century in India, but still the nation in general and the North-eastern region, in particular, is deprived of its healthcare infrastructure development. In the sense of health indicators like infant mortality, the life expectancy of birth, mortality rate, NER is still poor compared with the other states of India. Poor conditions of health infrastructure create a lot of problems such as non-availability of free medicines for rural poor, nonavailability of good doctors and lack of a sufficient number of government hospitals in rural areas of the country etc.

Objectives: The objectives of the study are to analyze the current status of rural healthcare infrastructure in the North- Eastern Region of India and to identify the challenges faced by the rural healthcare infrastructure of North East India.

Methods: The paper based on secondary data only. Data has been collected from different source such as Rural Health Statistics (RHS)- 2018-19 published by the Government of India Ministry of Health and Family Welfare Statistics Division, SRS Bulletin published by Office of The Registrar General, India, India HIV Estimates 2019 Report, published by National aids control organization, ICMR - National Institute of Medical Statistics, Ministry of health \& family welfare government of India and Database of Government of India (https://data.gov.in).

Results: NER of India has a shortfall of an adequate number of SCs, PHCs and CHCs particularly in rural areas as compared to the national average. The study found that the improvement of health care infrastructure in NER of India is unequal and therefore it is unsatisfactory.

Conclusion: There is an urgent need to take some policies by the government to establish some new SCs, PHCs in rural parts of the northeastern region of India and also the existing infrastructure needs to be improved through increasing the number of health workers with proper train.

Key Words: Rural Healthcare, Infrastructure, North-East, India, Challenges, SCs, PHCs, CHCs

\section{INTRODUCTION}

Health is one of the most important indicators of the human development index after education and standard of living (UNDP). Good health not only provides a hygienic life but also provides better work efficiency in the labour market. The growth of the health care infrastructure is important for the enhancement of the economic development of a nation. According to WHO, 2000 for a very long time, the main objective of most of the developing countries is to develop the health status of their citizens ${ }^{1}$. In a broad sense, it is a contributor to enhancing the expectancy of life and economic participation that leads to alleviation of poverty of a region. ${ }^{2}$
For any economic activities, infrastructure is necessary. So, it is defined, Infrastructure as the social capital or basic services of a country that make possible economic and social activities. ${ }^{3}$ There is a vast change seen in the twenty-first century in India, but still, the nation is deprived of its infrastructure development as compared to other nations of the world. Mainly the country still poor for its health sector compared with other developing countries of Asia i.e. China, Sri Lanka and Bangladesh. In the sense of health indicators like infant mortality, the life expectancy of birth, mortality under age five, India is still poor compared with the countries mentioned above. ${ }^{3}$ For the development of the health status of the citizens of the country, there is a need for ad-

\section{Corresponding Author:}

Manuranjan Gogoi, Assistant Professor (Contract), Department of Economics, Madhabdev University, Narayanpur, Assam-784164, India. Phone: +919859471709 (M); Email: manuranjan7@gmail.com

ISSN: 2231-2196 (Print)

Received: 15.11 .2020
ISSN: 0975-5241 (Online)

Revised: 04.03 .2021
Accepted: 18.05 .2021
Published: 05.07.2021 
equate health care infrastructure. According to Rural Health Statistics (RHS), 2018-19, Govt. of India, the total number of Sub Centres (SCs) are160713(157411 rural + 3302 urban) and they are functioning. Similarly, 30045 Primary Health Centres (PHCs) is functioning in India (24855 rural + 5190 urban) and there are 5685 Community Health Centres (CHCs) (5335 rural + 350 urban) functional in the country. But the current numbers of SCs, PHCs \& CHCs are not as per the IPHS norm. ${ }^{4,5}$

\section{DATA SOURCE}

The paper-based on secondary data only. Data has been collected from a different source such as Rural Health Statistics (RHS)- 2018-19 published by the Government of India Ministry of Health and Family Welfare Statistics Division, SRS Bulletin published by Office of The Registrar General, India, India HIV Estimates 2019 Report, published by National aids control organization, ICMR - National Institute of Medical Statistics, Ministry of health \& family welfare government of India and Database of Government of India (https://data.gov.in).

\section{PRESENT HEALTH STATUS OF NORTH-EAST INDIA}

The rural health care infrastructure of NER of India is still weaker than the states of the country. But after the implementation of NRHM, in 2005 there is a significant improvement seen in the region for its healthcare infrastructure. ${ }^{11}$ To analyze the current health status of NER, India the study focused on four indicators like- Birth Rate (BR), the Death rate (DR), Natural Growth Rate (NGR) and Infant Mortality Rate (IMR) of the region. The following Table 1 shows the four indicators that presented separately and categorized each of the indicators like- Total (T), Rural (R) and Urban (U). The total Birth rate of Assam and Meghalaya is more than of the national level (India). The same result happens in the case of rural birth rate also, but the only urban birth rate of all the states of north-east is lower than all India level (16.8). In the case of death rate, the total death rate of Assam (6.5) is higher than all India level (6.3). On the other hand, the rural death rate of all the states of NER is better to position in all India level (6.9) but in the case of urban death rate the states Assam and Manipur are in the same position with all India level (5.3) and the remaining six states are quite better positions than all India level. The natural growth rate of Assam and Meghalaya is greater than the national average also the same condition in the rural sector. But in urban NGR of Sikkim (14.9) is greater than all India average (11.6). In case of IMR the states Assam, Arunachal Pradesh and Meghalaya is shown the higher IMR than all India level(33) but the IMR of the remaining states is quite good than all India average. The state Nagaland is the most favoured states with the lowest IMR (7) among all the states of NER, India. The rural IMR of Assam, Arunachal Pradesh and Meghalaya is also higher than all India average, but in the case of urban IMR the states Arunachal Pradesh, Meghalaya and Tripura are in bad position than all India average. It is also mentionable that, the rural IMR (37) of India is higher than urban IMR (23), resulted from an inadequate health infrastructure of rural India. ${ }^{6,7}$

Table 1: Estimated Birth rate, Death rate, Natural growth rate and Infant mortality rate, 2017

\begin{tabular}{|c|c|c|c|c|c|c|c|c|c|c|c|c|}
\hline \multirow[t]{2}{*}{ States } & \multicolumn{3}{|c|}{ BR } & \multicolumn{3}{|c|}{ DR } & \multicolumn{3}{|c|}{ NGR } & \multicolumn{3}{|c|}{ IMR } \\
\hline & $\mathbf{T}$ & $\mathbf{R}$ & $\mathbf{U}$ & $\mathrm{T}$ & $\mathbf{R}$ & $\mathbf{U}$ & $\mathbf{T}$ & $\mathbf{R}$ & $\mathbf{U}$ & $\mathbf{T}$ & $\mathbf{R}$ & $\mathbf{U}$ \\
\hline $\begin{array}{l}\text { Arunachal } \\
\text { Pradesh }\end{array}$ & 18.3 & 18.8 & $15 \cdot 5$ & 6.1 & 6.4 & $4 \cdot 9$ & 12.1 & 12.4 & 10.6 & 42 & 44 & 34 \\
\hline Assam & 21.2 & 22.4 & 14.7 & 6.5 & 6.7 & $5 \cdot 3$ & 14.7 & 15.7 & 9.4 & 44 & 46 & 21 \\
\hline Manipur & 14.6 & 14.8 & 14.1 & $5 \cdot 3$ & $5 \cdot 3$ & $5 \cdot 3$ & 9.3 & $9 \cdot 5$ & 8.8 & 12 & 13 & 9 \\
\hline Meghalaya & 22.8 & 24.8 & 13.7 & 6.1 & 6.3 & 4.8 & 16.7 & 18.5 & 8.8 & 39 & 41 & 25 \\
\hline Mizoram & 15.0 & $17 \cdot 7$ & 12.2 & 4.0 & 4.0 & 4.1 & 11.0 & 13.8 & 8.0 & 15 & 20 & 7 \\
\hline Nagaland & 13.5 & 14.0 & 12.7 & 3.6 & 4.2 & 2.7 & 9.9 & 9.8 & $9 \cdot 9$ & 7 & 7 & 7 \\
\hline Sikkim & 16.4 & 15.2 & 18.3 & $4 \cdot 5$ & $5 \cdot 3$ & $3 \cdot 4$ & 11.9 & 9.9 & 14.9 & 12 & 13 & 9 \\
\hline Tripura & 13.0 & 14.1 & 10.3 & 5.2 & 5.2 & 5.2 & 7.8 & 9.0 & 5.1 & 29 & 28 & 32 \\
\hline India & 20.2 & 21.8 & 16.8 & 6.3 & 6.9 & $5 \cdot 3$ & 13.9 & 15.0 & 11.6 & 33 & 37 & 23 \\
\hline
\end{tabular}

Note: Infant mortality rates are based on the three years 2015-17.

Source: SRS Bulletin, Office of the Registrar General, India 
The health status of North-East India cannot be equally treated as shown in Table 1. This is because of the inadequate development of the health infrastructure or its unavailability of adequate manpower in the health sector. Poor conditions of health infrastructure of the country mean, there is a problem of non-availability of free medicines for rural poor, nonavailability of good doctors and lack of the sufficient number of government hospitals in rural areas of the country. ${ }^{12}$

Another serious health problem not only for North-East India but also the problem of the whole world is Acquired Immune Deficiency Syndrome (AIDS) disease. Still, there are no proper medicines invented for this disease for curing it. Just only a few preventive measures and active awareness among citizens can reduce it to spreading the disease. The present scenario of AIDS mortality of North-Eastern states and other Indian states/UTs represents the Figure 1 below-

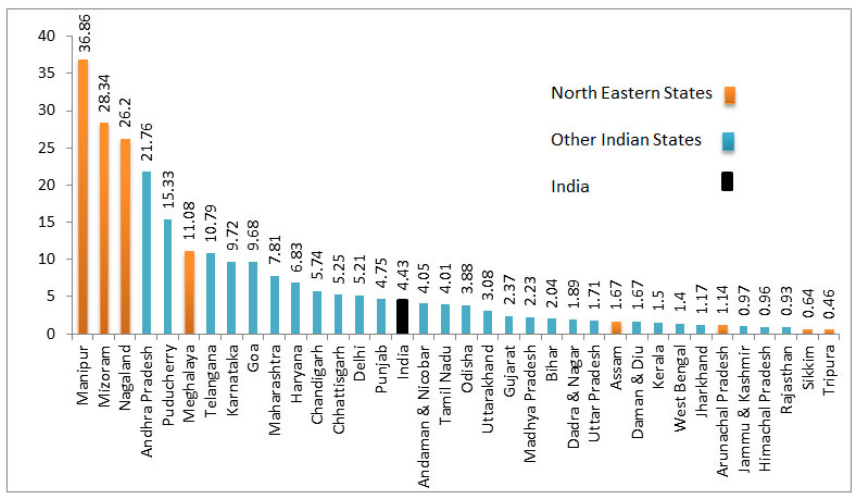

Figure 1: AIDS Mortality by State/UT, 2019 (per 100,000 population).

Source: India HIV Estimates-2019, Govt. of India
Figure 1 shows, AIDS-related mortality of India at 4.43 per 100,000 population in India.

State-wise AIDS-related mortality per 100,000 population, the three north-eastern states estimated to be in highest position all over India i.e. - Manipur (36.86), Mizoram (28.34) and Nagaland (26.2). This means inadequate health awareness of AIDS disease among the citizens of the states. Similarly, Meghalaya (11.08) is also in the fifth position after Andhra Pradesh (21.76) and Pondicherry (15.33). On the other hand, it is reflected in the figure; the states Assam (1.67), Arunachal Pradesh (1.14), Sikkim (0.64) and Tripura (0.46) are somewhere is in a better position and below the level of all India average (4.43). India HIV Estimates report 2019 also mentioned that the HIV-AIDS detected persons are gradually increasing all over the country. So it is a major concern for all human being. In this regards, there is a need for sufficient health infrastructure in the region as well.

\section{HEALTHCARE INFRASTRUCTURE OF NORTH- EAST INDIA}

The healthcare infrastructure in rural areas of India has been developed as a three-tier system i.e. - Sub Centres (SC), Primary Health Centres (PHCs) and Community Health Centres (CHCs). These three are the common health infrastructure of rural society. Mainly SCs and PHCs are the first and foremost choice of health care among rural civilian. Because these centres are situated in village level and they are nearest from the households. ${ }^{8,9}$ For critical cases, people preferred to go $\mathrm{CHCs}$ that are located mainly in semi-urban areas. The following Table 2 shows the rural population and average rural population covered by the health sector in NER.

Table 2: Average rural population covered by SCs, PHCs and CHCs

\begin{tabular}{|c|c|c|c|c|c|c|}
\hline \multirow[t]{2}{*}{ S1. No } & \multirow[t]{2}{*}{ State } & \multirow[t]{2}{*}{$\begin{array}{l}\text { Rural Population } \\
2011 \text { Census }\end{array}$} & \multirow{2}{*}{$\begin{array}{l}\text { Estimated mid-year Popula- } \\
\text { tion } 2019 \text { (as on 1st July 2019) } \\
\text { in Rural Areas }\end{array}$} & \multicolumn{3}{|c|}{$\begin{array}{l}\text { Average Rural Population [mid-year pop- } \\
\text { ulation as on 1st July 2019] covered by a }\end{array}$} \\
\hline & & & & SC & PHC & CHC \\
\hline 1 & $\begin{array}{l}\text { Arunachal } \\
\text { Pradesh }\end{array}$ & $1066358(77.06)^{*}$ & $\begin{array}{l}1133000 \\
(75.18)^{*}\end{array}$ & 2,943 & 7,923 & 17,984 \\
\hline 2 & Assam & $26807034(75.90)^{*}$ & $29208000(84.88)^{*}$ & 6,291 & 30,875 & $1,65,017$ \\
\hline 3 & Manipur & $2021640(70.79)^{*}$ & $\begin{array}{l}2132000 \\
(68.53)^{*}\end{array}$ & 4,351 & 23,689 & 92,696 \\
\hline 4 & Meghalaya & $2371439(79.93)^{*}$ & $\begin{array}{r}2569000 \\
(79.48)^{*}\end{array}$ & 5,386 & 21,771 & 91,750 \\
\hline 5 & Mizoram & $\begin{array}{l}525435 \\
(47.88)^{*}\end{array}$ & $\begin{array}{l}547000 \\
(45 \cdot 77)^{*}\end{array}$ & 1,478 & 9,271 & 60,778 \\
\hline 6 & Nagaland & $1407536(71.17)^{*}$ & $\begin{array}{l}1281000 \\
(59.44)^{*}\end{array}$ & 2,958 & 10,167 & 61,000 \\
\hline 7 & Sikkim & $\begin{array}{l}456999 \\
(74.84)^{*}\end{array}$ & $\begin{array}{l}389000 \\
(58.49)^{*}\end{array}$ & 2,210 & 13,414 & $1,94,500$ \\
\hline
\end{tabular}


Table 2: (Continued)

\begin{tabular}{ccccccc} 
S1. No & State & $\begin{array}{c}\text { Rural Population } \\
2011 \text { Census }\end{array}$ & $\begin{array}{c}\text { Estimated mid-year Popula- } \\
\text { tion 2019 (as on 1st July 2019) } \\
\text { in Rural Areas }\end{array}$ & $\begin{array}{c}\text { Average Rural Population [mid-year pop- } \\
\text { ulation as on 1st July 2019] covered by a } \\
\text { SC }\end{array}$ & $\begin{array}{c}\text { PHC } \\
\text { SHC }\end{array}$ \\
\hline 8 & Tripura & $2712464(73.83)^{*}$ & $\begin{array}{c}2595000 \\
(64.84)^{*}\end{array}$ & 2,670 & 24,028 & $1,44,167$ \\
9 & India & $\begin{array}{c}833748852 \\
(68.85)^{*}\end{array}$ & $\begin{array}{c}884021000 \\
(66.09)^{*}\end{array}$ & 5,616 & 35,567 & $1,65,702$ \\
\hline
\end{tabular}

Note*: The percentage share of the population to the total population.

Source: Rural Health Statistics 2018-19, Govt. of India

Table 2 shows the rural population of all the NE states in the year 2011 and 2019. It also shows the average population covered by the health services of those states. In the case of SCs, only Assam is in a better position than the national average. Similarly, the conditions of PHCs of all the NE states are very poor and it was lower than the national average. On the other hand, in the case of CHCs, only Sikkim is in a better position than the national average.

\section{CHALLENGES FACED BY THE RURAL HEALTH- CARE INFRASTRUCTURE OF NORTH-EAST INDIA}

\section{Position of SCs, PHCs and CHCs}

Rural healthcare services of the North-eastern states of India facing many problems for many decades but in some aspects, the states of the region are in a good position than the other states of India. Some of the states of the region do not have an adequate number of SCs, PHCs and CHCs in the rural areas. The following Table 3 is trying to show the present status of rural healthcare centres in the North-eastern states of India.

Table 3: Shortfall of SCs, PHCs and CHCs as per estimation of the mid-year population (as of 1st July 2019) in rural areas of North-East India

\begin{tabular}{|c|c|c|c|c|c|c|c|c|c|c|}
\hline \multirow[b]{2}{*}{ States } & \multirow[t]{2}{*}{$\begin{array}{l}\text { Estimated mid- } \\
\text { year population } \\
\text { for Rural areas }\end{array}$} & \multicolumn{3}{|c|}{ SCs } & \multicolumn{3}{|c|}{ PHCs } & \multicolumn{3}{|c|}{ CHCs } \\
\hline & & $\mathbf{R}$ & $\mathbf{P}$ & S & $\mathbf{R}$ & $\mathbf{P}$ & $S$ & $\mathbf{R}$ & $\mathbf{P}$ & S \\
\hline $\begin{array}{l}\text { Arunachal } \\
\text { Pradesh }\end{array}$ & 1133000 & 338 & 385 & + & 51 & 143 & + & 12 & 63 & + \\
\hline Assam & 29208000 & 6374 & 4643 & 1731 & 1040 & 946 & 94 & 260 & 177 & 83 \\
\hline Manipur & 2132000 & 537 & 490 & 47 & 84 & 90 & + & 21 & 23 & + \\
\hline Meghalaya & 2569000 & 822 & 477 & 345 & 124 & 118 & 6 & 31 & 28 & 3 \\
\hline Mizoram & 547000 & 179 & 370 & + & 27 & 59 & + & 6 & 9 & + \\
\hline Nagaland & 1281000 & 414 & 433 & + & 62 & 126 & + & 15 & 21 & + \\
\hline Sikkim & 389000 & 96 & 176 & + & 15 & 29 & + & 3 & 2 & 1 \\
\hline Tripura & 2595000 & 661 & 972 & + & 104 & 108 & + & 26 & 18 & 8 \\
\hline All India/ Total & 874021000 & 189765 & 157411 & 43736 & 31074 & 24855 & 8764 & $775^{6}$ & 5335 & 2865 \\
\hline
\end{tabular}

Notes: The requirement is calculated using the prescribed norms based on rural population estimation for mid-year for the year 2019.

R: Required; P: In Position; S: Shortfall;+: Surplus

Source: Rural Health Statistics 2018-19, Govt. of India 
Table 3 shows the SCs in rural areas of Assam, Manipur and Meghalaya still inadequate with the size of its population and shown a shortfall of rural SCs 1731, 47, 345respectively. But the state Arunachal Pradesh, Mizoram, Nagaland, Sikkim and Tripura have surplus SCs. Similarly, Assam and Meghalaya have a shortfall of rural PHCs 94 and 6 respectively but the other states of NER have in a better position with surplus values. In the case of $\mathrm{CHCs}$, the states Assam, Meghalaya Sikkim and Tripura is facing a problem of unavailability of sufficient community health centres. From this analysis, it is noticeable that the state Assam and Meghalaya have a shortfall of all three types of healthcare infrastructure in the rural areas of those states. In the case of Assam, the health status of the rural areas is poorer than the urban areas ${ }^{1}$. In the case of all India level, there is also a huge shortfall seen in all three categories. It is implied that the health infrastructure of the country was still inappropriate. ${ }^{10}$

\section{Status of manpower in rural healthcare ser- vices}

Healthcare infrastructure will not be sufficient if adequate manpower is not available to provide the services. The states of the North-East are in a good position for its female health workers/ ANMs in rural SCs accept Sikkim and Tripura. There is a shortfall of 24 and 388 of these two states. But the other states of the region are having surplus female workers in SCs of rural areas as per IPHS norms. ${ }^{11}$ In the case of male health worker in rural SCs, there is a huge deficiency (98063) shown all over the country including NER. Similarly, the availability of doctors, health workers in PHCs is also very important. Because the people of rural areas preferred the PHCs as their first choice if they facing general healthrelated problems. The following Table 4 shows the present status of rural PHCs of NER in terms of their availability of doctors and other health workers as per IPHS norms.

Table 4: Availability of Doctors and other health workers in rural PHCs of NER (As of 31st March 2019)

\begin{tabular}{|c|c|c|c|c|c|c|c|}
\hline States & $\begin{array}{l}\text { Shortfall of } \\
\text { Doctors }\end{array}$ & $\begin{array}{l}\text { The shortfall } \\
\text { of health } \\
\text { worker [fe- } \\
\text { male] / ANM }\end{array}$ & $\begin{array}{l}\text { Shortfall of } \\
\text { Health assis- } \\
\text { tants [female] } \\
\text { / LHV }\end{array}$ & $\begin{array}{l}\text { The shortfall } \\
\text { of Health as- } \\
\text { sistant } \\
\text { [male] }\end{array}$ & $\begin{array}{l}\text { Shortfall of } \\
\text { Pharmacists }\end{array}$ & $\begin{array}{l}\text { Shortfall } \\
\text { of Laboratory } \\
\text { Technicians }\end{array}$ & $\begin{array}{l}\text { Shortfall of } \\
\text { Nursing Staff }\end{array}$ \\
\hline $\begin{array}{l}\text { Arunachal } \\
\text { Pradesh }\end{array}$ & 27 & + & 126 & 62 & 88 & 93 & + \\
\hline Assam & + & + & 694 & 946 & + & + & + \\
\hline Manipur & + & + & 26 & 90 & + & 39 & + \\
\hline Meghalaya & + & + & 11 & 21 & + & + & + \\
\hline Mizoram & + & 33 & 40 & 37 & 11 & + & + \\
\hline Nagaland & + & + & 126 & 126 & 32 & 52 & + \\
\hline Sikkim & + & + & 12 & 16 & 16 & $\mathrm{o}$ & + \\
\hline Tripura & + & 28 & 108 & 102 & + & 11 & + \\
\hline
\end{tabular}

Note: calculated as per IPHS norms, +: Surplus

Source: Rural Health Statistics 2018-19, Govt. of India

As per IPHS norms, there is one doctor, one female health worker/ANM, one Health Assistant [Female] / LHV, one Health Assistant [Male], one pharmacist, one laboratory technician, one nursing staff is necessary for each PHC. Table 4 shows, surplus doctors are available in rural PHCs of all the states of NER except Arunachal Pradesh. Similarly, two states Mizoram and Tripura have insufficient female health worker/ANM in their rural PHCs but the other states of NER have surplus female health worker/ANM. In the case of health assistant (Male and Female), there is a huge shortfall in every state of the region which means violation of IPHS norms. On the other hand the states Arunachal
Pradesh, Mizoram, Nagaland and Sikkim facing a shortage of pharmacists in rural PHCs as per IPHS norms. Similarly, Arunachal Pradesh, Manipur, Nagaland and Tripura are facing the problem of insufficient laboratory technicians in rural PHCs. It is also mentionable that there are surplus nursing pieces of stuff are available in all the states of NER. ${ }^{12}$ It is a positive sign for rural healthcare service in the region.

The role of CHCs is very significant for rural people of the country. During a serious disease or other serious healthrelated problems, people of the rural areas prefer the CHCs. The present situation of CHCs based on the availability of manpower in NER is shown in the following Table 5. 
Table 5: Availability of Doctors and other health workers in rural CHCs of NER (As of 31st March 2019

\begin{tabular}{|c|c|c|c|c|c|c|c|}
\hline \multirow[b]{2}{*}{ States } & \multicolumn{7}{|c|}{ Manpower in CHCs of NE States (As on 31st March, 2019) } \\
\hline & $\begin{array}{l}\text { Shortfall } \\
\text { of } \\
\text { AYUSH } \\
\text { Doctors at } \\
\text { CHCs }\end{array}$ & $\begin{array}{c}\text { Shortfall of } \\
\text { Total Special- } \\
\text { ists [Surgeons, } \\
\text { OB\&GY, Physi- } \\
\text { cians \&Paedia- } \\
\text { trician] }\end{array}$ & $\begin{array}{l}\text { Shortfall of } \\
\text { General Duty } \\
\text { Medical Offic- } \\
\text { ers (GDMOs) } \\
\text { - Allopathic }\end{array}$ & $\begin{array}{c}\text { Shortfall of } \\
\text { Radiogra- } \\
\text { phers at } \\
\text { CHCs }\end{array}$ & $\begin{array}{l}\text { Shortfall of } \\
\text { Pharmacists } \\
\text { at CHCs }\end{array}$ & $\begin{array}{l}\text { Shortfall of } \\
\text { Laboratory } \\
\text { Technicians } \\
\text { at CHCs }\end{array}$ & $\begin{array}{c}\text { Shortfall of } \\
\text { Nursing Staff } \\
\text { at CHCs }\end{array}$ \\
\hline $\begin{array}{l}\text { Arunachal } \\
\text { Pradesh }\end{array}$ & 7 & 248 & 11 & 46 & 17 & o & + \\
\hline Assam & 91 & 572 & + & 87 & + & + & 47 \\
\hline Manipur & + & 89 & + & + & + & + & + \\
\hline Meghalaya & 5 & 108 & + & 10 & + & + & + \\
\hline Mizoram & 3 & 36 & 3 & 4 & 1 & + & 12 \\
\hline Nagaland & o & 76 & 9 & 18 & + & + & + \\
\hline Sikkim & o & 8 & o & + & o & + & + \\
\hline Tripura & 2 & 70 & + & 7 & + & + & + \\
\hline
\end{tabular}

Note: calculated as per IPHS norms, +: Surplus

Source: Rural Health Statistics 2018-19, Govt. of India

Table 5 shows only Manipur has the surplus AYUSH doctors, Nagaland and Sikkim has also adequate numbers. But the other states of the region have not an adequate number of AYUSH doctors in their CHCs located in the rural areas. Similarly, all the states of the region have a shortfall of total specialist doctors (Surgeons, OB \& GY, Physicians and Pediatrician) in rural CHCs. On the other hand, Arunachal Pradesh, Mizoram and Nagaland have an inadequate number of General Duty Medical Officers- Allopathic. In the case of radiographers in rural CHCs, only Manipur and Sikkim has the surplus numbers. There is a shortfall of pharmacists shown in the case of Arunachal Pradesh and Mizoram. In the case of Laboratory technicians, all the states of NER have an adequate number of manpower and it is a positive sign for the health sector of the region. But at the same time, Assam (47) and Mizoram (12) has a shortfall of nursing staffs of rural CHCs. ${ }^{13}$

\section{Status of building positions of the health sec- tor in NER}

Basic infrastructure facilities are necessary to provide good health services among citizens. In the north-Eastern states, the basic infrastructure facilities of the rural health sector are not very well but comparatively better in some states than other states of the country. One of the basic infrastructures is building facilities. The current status of building facilities in the rural health sector discussed below.

Building position of SCs: According to RHS 18-19, Arunachal Pradesh, Mizoram and Sikkim have an adequate number of government buildings. On the other hand, there is a deficiency of government buildings in other states of NER that accept these three states. Assam has the highest deficiency of buildings and required around 594 buildings. This has resulted in Assam; a government package is required to construct new buildings in rural areas mainly for SCs. The following Table 6 shows the current building position of SCs in NER.

Table 6: Building position of SCs in rural areas of North-East India

\begin{tabular}{|c|c|c|c|c|c|c|}
\hline \multirow[t]{2}{*}{ States } & \multirow{2}{*}{$\begin{array}{l}\text { Total Number of } \\
\text { Sub Centers }\end{array}$} & \multicolumn{3}{|c|}{ Sub-Centres } & \multirow{2}{*}{$\begin{array}{l}\text { Buildings Under } \\
\text { Construction }\end{array}$} & \multirow{2}{*}{$\begin{array}{l}\text { Buildings } \\
\text { required to be } \\
\text { constructed }\end{array}$} \\
\hline & & Govt. Buildings & $\begin{array}{l}\text { Rented } \\
\text { Buildings }\end{array}$ & $\begin{array}{c}\text { Rent Free } \\
\text { Panchayat / } \\
\text { Vol. Society } \\
\text { Buildings }\end{array}$ & & \\
\hline $\begin{array}{l}\text { Arunachal } \\
\text { Pradesh }\end{array}$ & 385 & 385 & o & o & o & o \\
\hline Assam & 4643 & 4049 & 466 & 128 & o & 594 \\
\hline Manipur & 490 & 459 & 31 & o & 18 & 13 \\
\hline
\end{tabular}


Table 6: (Continued)

\begin{tabular}{|c|c|c|c|c|c|c|}
\hline \multirow[t]{2}{*}{ States } & \multirow{2}{*}{$\begin{array}{l}\text { Total Number of } \\
\text { Sub Centers }\end{array}$} & \multicolumn{3}{|c|}{ Sub-Centres } & \multirow{2}{*}{$\begin{array}{l}\text { Buildings Under } \\
\text { Construction }\end{array}$} & \multirow{2}{*}{$\begin{array}{l}\text { Buildings } \\
\text { required to be } \\
\text { constructed }\end{array}$} \\
\hline & & Govt. Buildings & $\begin{array}{l}\text { Rented } \\
\text { Buildings }\end{array}$ & $\begin{array}{l}\text { Rent Free } \\
\text { Panchayat / } \\
\text { Vol. Society } \\
\text { Buildings }\end{array}$ & & \\
\hline Meghalaya & 477 & 468 & 2 & 7 & $\mathrm{o}$ & 9 \\
\hline Mizoram & 370 & 370 & o & o & o & o \\
\hline Nagaland & 433 & 316 & 1 & 116 & 59 & 58 \\
\hline Sikkim & 176 & 175 & 1 & o & 1 & o \\
\hline Tripura & 972 & 810 & 28 & 134 & 17 & 145 \\
\hline
\end{tabular}

Notes: Required number of building to be constructed = Total functioning - (Government Buildings + Under construction) (ignoring States having excess.)

Source: Rural Health Statistics 2018-19, Govt. of India

Building position of PHCs: As per rural health statistics 2018-19, accept Nagaland all the states of northeast India has the sufficient number of building in rural PHCs. There is a shortfall of building only in Nagaland and it was 7 only. Overall the northeastern states are in a better position in the case of buildings of their PHCs.

Building position of CHCs: In all the North-Eastern states there is a sufficient number of PHC buildings are available, even there is an additional building is available in Tripura ${ }^{10}$. It implies that basic infrastructure facilities in the case of buildings in all the states of NER are in a better position.

\section{FINDINGS \& CONCLUSION}

The study attempted to examine the current status of rural healthcare infrastructure of the North-Eastern Region of India in terms of birth rate, death rate, natural growth rate and infant mortality rate. Though it is found that the rural death rate of all the states of NER is lower than all India level, in the case of other indicators, it is not good. It also discussed a serious health disease called AIDS and its current status on the NE States through mortality rate and found this is a serious health issue for this region. Similarly, in the case of the healthcare infrastructure of NER, almost all the states of northeast India are lacking better condition of SCs, PHCs as compared to the national average. Some of the states of this region do not have an adequate number of SCs, PHCs and CHCs, particularly in rural areas. It has also a shortfall in terms of availability of doctors, nursing staffs etc. which need to be increased with proper training. The study found that the improvement of health care infrastructure in NER of India is unequal and therefore it is unsatisfactory. There is an urgent need to take some policies by the government to establish some new SCs, PHCs in rural parts of the north eastern region of India and also the existing infrastructure needs to be improved through increasing the number of health workers with proper train.

\section{Acknowledgement: Nil}

\section{Conflict of interest: Nil}

Funding Source: No Funding sources were granted

Authors' Contribution: The whole work is a collaborative one and has equal contribution i.e- search the data and analyze the data to get an efficient result.

\section{Abbreviations:}

- ANM: Auxiliary Nurse Midwife

- AYUSH: Ayurveda, Yoga \& Naturopathy, Unani, Siddha and Homoeopathy

- CHCs: Community Health Centre

- GOI: Government of India

- ICMR: Indian Council of Medical Research

- IPHS: Indian Public Health Standards

- LHV: Lady Health Visitor

- NE: North- East

- NER: North-Eastern Region

- NRHM: National Rural Health Mission

- PHC: Primary Health Centre

- RHS: Rural Health Statistics

- SC: Sub Centre

- UNDP: United Nations Development Programme

- WHO: World Health Organization

\section{REFERENCES}

1. Buragohain P.P. Status of rural health infrastructure of Assam. Int J Manag Soc Sci Res Rev. 2015; 1(15): 210-218.

2. Das S. Rural Health Status and Health Care in North-Eastern India: A Case Study. J Health Manag. 2012; 14(3): 283-296.

3. GOI. Report of the National Commission on Macroeconomics and Health, Ministry of Health and Family Welfare. Government of India, 2005. 
4. India HIV Estimates 2019 Report, National Aids Control Organization | ICMR - National Institute of Medical Statistics Ministry of Health \& Family Welfare, Government of India. 2019.

5. Lyngdoh L M. Inter-State Variations in Rural Healthcare Infrastructure in North-East India. Nehu J. 2015; 13 (2): 31-48.

6. Mal S, Bhattacharya P, Ghosh B. Consequence of health infrastructure of northeast India in comparison with India. Radix Int J Res Soc Sci. 2013; 2(7): 1-14.

7. National Family Health Survey (NFHS-4) India. Ministry of Health and Family Welfare, Government of India.2016.

8. Paul P K, Jana S K, Maiti A. An Analysis of Health Status of the State of Assam, India.Res Rev Int J Multidisc. 2019; 4(9): 1179-1188.
9. Rutherford D. Dictionary of Economics. Second Edition. Routledge. London and New York. 2002.

10. Rural Health Statistics 2018. Government of India Ministry of Health and Family Welfare Statistics Division.2018.

11. Saikia D. Health Care Infrastructure in the Rural Areas of NorthEast India: Current Status and Future Challenges. J Eco Soc Develop. 2014; 10 (1): 83-99.

12. Saikia D. Das KK. Rural Health Infrastructures in the NorthEast. http://mpra.ub.uni-muenchen.de/41859/2012: 1-10.

13. The World Health Report.2000. Health Systems: Improving Performance. World Health Organization. 